\title{
FAKTOR KARAKTERISTIK PEKERJA TERHADAP PRODUKTIVITAS DI SEKTOR PERDAGANGAN, RUMAH MAKAN, DAN JASA AKOMODASI TAHUN 2010-2017
}

\author{
(Factors Characteristic of Workers on Productivity in the Trade, Restaurant, and \\ Accomodation Services Sector in 2010-2017) \\ Farikha Fia Fatmawati, Ekaria \\ Politeknik Statistika STIS \\ Jalan Otto Iskandardinata No.64C, Jakarta Timur 13330 \\ E-mail: 15.8613@stis.ac.id
}

\begin{abstract}
ABSTRAK
Sektor perdagangan, rumah makan, dan jasa akomodasi merupakan salah satu sektor yang mendominasi perekonomian Indonesia. Hal ini dibuktikan dengan kontribusinya terhadap PDB Indonesia yang merupakan tertinggi kedua setelah sektor industri, yaitu sebesar $15,86 \%$ pada tahun 2017. Namun, kontribusi yang tinggi ini ternyata menurun sejak tahun 2015 sampai tahun 2017. Penurunan ini tidak sejalan dengan jumlah pekerja dan upah yang terus meningkat di sektor perdagangan, rumah makan, dan jasa akomodasi. Dalam upaya untuk meningkatkan kontribusi PDB sektor ini, hal penting yang harus ditingkatkan adalah produktivitas pekerjanya. Untuk itu, perlu diperhatikan faktor karakteristik pekerja yang memengaruhi produktivitasnya. Penelitian ini bertujuan untuk menganalisis faktor karakteristik pekerja terhadap produktivitas di sektor perdagangan, rumah makan, dan jasa akomodasi. Metode yang digunakan dalam penelitian ini adalah analisis regresi data panel. Hasil dari penelitian yang menggunakan model efek acak ini menunjukkan bahwa tingkat pendidikan pekerja, pengalaman kerja, tingkat upah, dan jumlah pekerja berpengaruh positif dan signifikan terhadap produktivitas pekerja sektor perdagangan, rumah makan, dan jasa akomodasi. Oleh karena itu, faktor karakteristik pekerja tersebut perlu diperhatikan oleh pemerintah dalam upaya untuk meningkatkan produktivitas pekerja sektor perdagangan, rumah makan, dan jasa akomodasi.
\end{abstract}

Kata kunci: produktivitas pekerja, regresi data panel, model efek acak

\section{ABSTRACT}

The trade, restaurants, and accommodation services sectors are one of the sectors that dominate Indonesian economy. This is evidenced by its contribution to Indonesia's GDP which is the second highest after industrial sector, which amounted to $15.86 \%$ in 2017 . However, this high contribution has declined from 2015 to 2017. This decline was not in line with the number of workers and wages that increase in the trade, restaurants, and accommodation services sectors. To increase the contribution of GDP of this sector, the important thing that must be improved is the labor productivity. Hence, it is necessary to consider the characteristics of workers that affect their productivity. This study aims to analyze the characteristics of workers that affect labor productivity in the trade, restaurants, and accommodation services sectors. The method used in this study is panel data regression analysis. The results using random effects model show that education levels of workers, work experience, wage rates, and number of workers have a positive and significant effect on labor productivity in the trade, restaurants, and accommodation services sectors. Therefore, the characteristics of these workers need to be considered by the government to increase the labor productivity in the trade, restaurants, and accommodation services sectors.

Keywords: labor productivity, panel data regression, random effects model

\section{PENDAHULUAN}

Indonesia sebagai salah satu negara berkembang, tentu sedang gencar dalam melaksanakan pembangunan. Secara tradisional, pembangunan dalam istilah ekonomi diartikan sebagai tercapainya tingkat pertumbuhan pendapatan per kapita yang berkelanjutan, yang memungkinkan negara dapat mengembangkan outputnya pada tingkat yang lebih cepat daripada pertumbuhan penduduknya (Todaro \& Smith, 2015). Selain itu, Todaro \& Smith juga mendefinisikan pembangunan sebagai suatu proses untuk meningkatkan kualitas semua kehidupan dan kemampuan manusia dengan meningkatkan standar hidup, harga diri, dan kebebasan. Tiga tujuan pokok dari 
pembangunan ini adalah meningkatkan ketersediaan kebutuhan pokok, meningkatkan standar kehidupan atau rasa harga diri, dan memperluas kebebasan untuk memilih.

Produk Domestik Bruto (PDB) merupakan salah satu indikator penting yang dapat menggambarkan besarnya pendapatan suatu negara. Berdasarkan data Badan Pusat Statistik (BPS) (2017c), PDB per kapita penduduk Indonesia tumbuh meningkat sejak tahun 2010 sampai tahun 2016. Hal ini menunjukkan adanya pembangunan dalam arti ekonomi tradisional. Besarnya PDB Indonesia ini dapat didistribusikan ke dalam sembilan sektor ekonomi untuk melihat besarnya kontribusi masing-masing sektor dalam menyumbang nilai PDB Indonesia. Tiga sektor terbesar yang menyumbang PDB Indonesia adalah industri pengolahan; perdagangan, rumah makan, dan jasa akomodasi; dan pertanian. Sektor-sektor yang memberikan sumbangan yang besar inilah yang memengaruhi pergeseran perekonomian di Indonesia.

Menurut Todaro \& Smith (2015), selain untuk meningkatkan pendapatan, tujuan dalam pembangunan juga untuk meningkatkan ketersediaan pekerjaan. Berdasarkan data BPS (2017b), jumlah penduduk usia lima belas tahun ke atas yang bekerja cenderung mengalami peningkatan sejak tahun 2010 sampai 2017. Sementara itu, bila dilihat berdasarkan sektornya, sektor ekonomi yang paling banyak menyerap tenaga kerja di Indonesia adalah sektor pertanian. Selanjutnya disusul oleh sektor perdagangan, rumah makan, dan jasa akomodasi, lalu sektor jasa kemasyarakatan.

Berdasarkan uraian di atas, terlihat bahwa sektor ekonomi yang perlu difokuskan di Indonesia adalah sektor perdagangan, rumah makan, dan jasa akomodasi. Hal ini sesuai dengan tujuan pembangunan berkelanjutan (Sustainable Development Goals) butir delapan, yaitu untuk mendukung pertumbuhan ekonomi berkelanjutan dan tenaga kerja yang produktif. Salah satu target pembangunan dalam tujuan ke delapan ini adalah mencapai produktivitas yang lebih tinggi dengan memfokuskan sektor yang memiliki nilai tambah lebih dan bersifat padat karya.

Namun berdasarkan data BPS, ternyata kontribusi PDB sektor perdagangan, rumah makan, dan jasa akomodasi ini justru mengalami penurunan sejak tahun 2015, sebagaimana dapat dilihat pada Gambar 1. Hal ini tidak sejalan dengan peningkatan dalam penyerapan tenaga kerja di sektor tersebut.

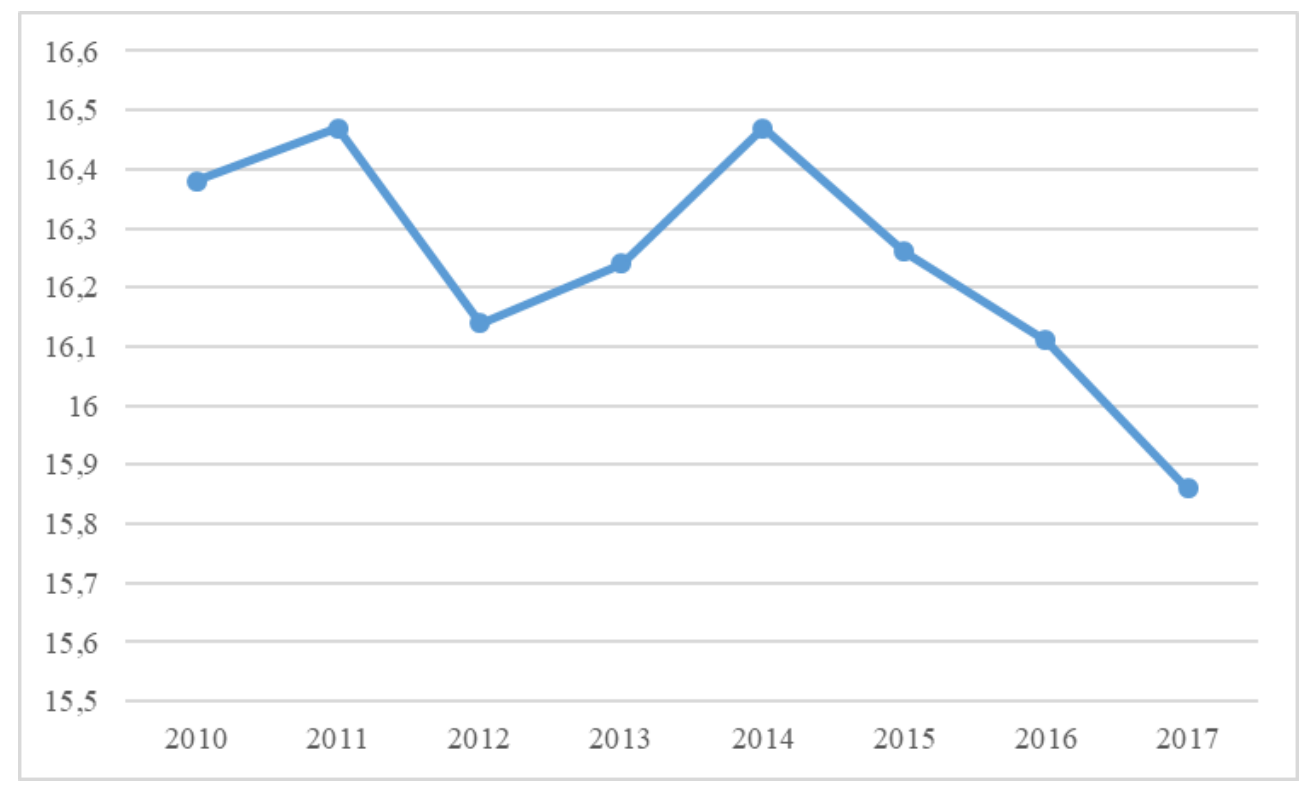

Sumber: Badan Pusat Statistik

Gambar 1. Kontribusi PDB (persen) sektor perdagangan, rumah makan, dan jasa akomodasi di Indonesia tahun 2010-2017.

Dalam upaya untuk meningkatkan kontribusi PDB sektor perdagangan, rumah makan, dan jasa akomodasi, hal penting yang harus ditingkatkan terlebih dahulu adalah produktivitas pekerjanya. Jika produktivitas pekerja tinggi maka produksi yang dihasilkan juga akan tinggi sehingga kontribusi PDB-nya akan meningkat. Sebagaimana yang telah dinyatakan oleh International Labour Organization (ILO) (2015), bahwa produktivitas pekerja merupakan hal yang perlu diperhatikan dalam peningkatan standar hidup. Standar hidup yang meningkat dapat menggambarkan adanya 
peningkatan pendapatan. Bila pendapatan meningkat maka kemampuan masyarakat untuk mengonsumsi barang/jasa juga meningkat sehingga PDB akan meningkat.

Permasalahan produktivitas pekerja ini dapat dipengaruhi oleh berbagai faktor. Dalam hal ini, produktivitas pekerja merupakan sesuatu yang tidak dapat diukur langsung sehingga perlu diketahui faktor karakteristik dari pekerja yang dapat meningkatkan produktivitasnya itu. Dalam publikasi Organisation for Economic Co-operation and Development (2018), disebutkan bahwa kompensasi pekerja berkorelasi erat dengan tingkat produktivitasnya. Hal ini diartikan bahwa semakin banyak pekerjaan yang memiliki produktivitas pekerja rendah, maka semakin banyak pula pekerjaan dengan tingkat upah di bawah rata-rata upah nasional. Selain itu, disebutkan juga bahwa efektivitas pekerja tidak hanya tergantung pada jam kerja dan upah, namun juga tergantung pada tingkat pendidikan, pengalaman kerja, fungsi bisnis, dan karakteristik pekerja yang lainnya. Oleh karena itu, penelitian ini bertujuan untuk mengetahui perkembangan produktivitas pekerja di sektor perdagangan, rumah makan, dan jasa akomodasi menurut provinsi-provinsi dominan dan menganalisis faktor karakteristik pekerja yang memengaruhi produktivitas di sektor tersebut tahun 2010-2017.

\section{METODE}

Data yang digunakan dalam penelitian ini adalah data sekunder yang diperoleh dari publikasi Badan Pusat Statistik (BPS) dan hasil survei angkatan kerja nasional (sakernas) periode Agustus untuk sektor perdagangan, rumah makan, dan jasa akomodasi. Data panel yang digunakan adalah periode 2010-2017 dan mencakup 14 provinsi yang dominan di sektor perdagangan, rumah makan, dan jasa akomodasi. Pemilihan provinsi ini berdasarkan urutan share PDRB menurut sektor ekonomi di masing-masing provinsi di Indonesia. Provinsi yang terpilih merupakan provinsi yang memiliki share PDRB sektor perdagangan, rumah makan, dan jasa akomodasi pada urutan tertinggi pertama dan kedua di masing-masing provinsi. Provinsi dominan ini adalah Aceh, Sumatera Barat, Bengkulu, DKI Jakarta, Jawa Barat, Jawa Tengah, DI Yogyakarta, Jawa Timur, Banten, Bali, Sulawesi Utara, Sulawesi Selatan, Gorontalo, dan Sulawesi Barat.

Variabel terikat yang digunakan dalam penelitian ini adalah produktivitas pekerja di sektor perdagangan, rumah makan, dan jasa akomodasi. Untuk menganalisis faktor karakteristik pekerja yang memengaruhi produktivitas di sektor tersebut, maka variabel bebas yang digunakan adalah jenis kelamin, tingkat pendidikan pekerja, pengalaman kerja, tingkat upah, dan jumlah pekerja. Berikut ini penjelasan mengenai ukuran yang digunakan oleh masing-masing variabel:

1. Produktivitas pekerja diukur dengan rata-rata upah dibagi jam kerja.

2. Jenis kelamin diukur dengan persentase pekerja yang berjenis kelamin laki-laki.

3. Tingkat pendidikan pekerja diukur dengan persentase pekerja yang memiliki ijazah SMA/sederajat ke atas.

4. Pengalaman kerja diukur dengan lama bekerja dari pekerja.

5. Tingkat upah diukur dengan upah minimum provinsi.

6. Jumlah pekerja diukur dengan total pekerja.

Metode analisis yang digunakan dalam penelitian ini terdiri atas analisis deskriptif dan analisis inferensia. Analisis deskriptif akan disajikan dalam bentuk grafik dengan menggunakan aplikasi Microsoft Excel 2016 untuk mengetahui perkembangan produktivitas pekerja di sektor perdagangan, rumah makan, dan jasa akomodasi. Sementara itu, analisis inferensia menggunakan analisis regresi data panel dengan menggunakan aplikasi EViews 10 berguna untuk menganalisis faktor karakteristik pekerja yang memengaruhi produktivitas di sektor perdagangan, rumah makan, dan jasa akomodasi. Model regresi data panel dalam penelitian ini dapat dituliskan sebagai berikut:

$$
\begin{aligned}
& L_{-}{ }_{-} P R O D_{i t}=\alpha+\beta_{1} J K_{i t}+\beta_{2} \text { PENDIDIKAN } i t+\beta_{3} \text { PENGALAMAN } i t+\beta_{4} U_{\text {UMP }}+ \\
& \beta_{5} P E K E R J A_{i t}+u_{i t}
\end{aligned}
$$

dimana:

$\mathrm{t}$

$\alpha$

$\mathrm{i}=$ Aceh, ..., Sulawesi Barat

$$
\begin{array}{ll}
\text { : jumlah provinsi (cross section) } & \mathrm{i}=\text { Aceh, ..., Sulawe } \\
\text { : jumlah tahun (time series) } & \mathrm{t}=2010, \ldots, 2017 \\
: \text { intercept } &
\end{array}
$$$$
\text { : slope variabel bebas ke- } \mathrm{K} \text {, dengan } \mathrm{K}=1,2,3,4,5
$$ 
$L N_{-} P R O D_{i t} \quad$ : logaritma natural dari produktivitas pekerja di sektor perdagangan, rumah makan, dan jasa akomodasi provinsi ke-i pada tahun ke-t (rupiah per jam)

$J K_{i t} \quad$ : persentase pekerja sektor perdagangan, rumah makan, dan jasa akomodasi yang berjenis kelamin laki-laki provinsi ke-i pada tahun ke-t (persen)

PENDIDIKAN $N_{i t}$ : persentase pekerja sektor perdagangan, rumah makan, dan jasa akomodasi dengan ijazah SMA/sederajat ke atas provinsi ke-i pada tahun ke-t (persen)

PENGALAMAN ${ }_{i t}$ : lama bekerja pekerja sektor perdagangan, rumah makan, dan jasa akomodasi provinsi ke-i pada tahun ke-t (bulan)

$U M P_{i t} \quad$ : upah minimum provinsi ke-i pada tahun ke-t (rupiah)

PEKERJA $\quad$ : jumlah pekerja sektor perdagangan, rumah makan, dan jasa akomodasi provinsi ke-i pada tahun ke-t (jiwa)

$u_{i t} \quad$ : komponen eror provinsi ke-i pada tahun ke-t

Berikut tahapan analisis regresi data panel yang digunakan dalam penelitian ini:

1. Pemilihan model terbaik adalah dengan menggunakan Uji Hausman. Hal ini dikarenakan adanya penetapan individu yang digunakan dalam penelitian ini, namun pengambilan individu didasarkan pada besarnya share PDRB dari masing-masing provinsi sehingga model yang diduga adalah FEM atau REM. Pengujian ini dilakukan untuk memilih apakah pengaruh efek individu lebih besar daripada pengaruh efek acak dari komponen eror. Bila model yang terpilih selanjutnya adalah FEM, maka dilanjutkan pengujian struktur varians-kovarians residual dari model FEM ini. Pengujian struktur varians-kovarians residual ini terdiri dari Uji Lagrange Multiplier (heteroskedastisitas) dan Uji Breusch-Pagan Lagrange Multiplier (cross-sectional correlation).

2. Pengujian asumsi klasik regresi, yaitu menggunakan residual yang dihasilkan oleh model yang terpilih sebagai model terbaik. Terdapat empat asumsi regresi yang harus dipenuhi, yaitu normalitas, homoskedastisitas, non-autokorelasi, dan non-multikolinieritas. Bila residual dari model yang terpilih dapat memenuhi semua asumsi tersebut maka model dapat menggunakan estimasi ordinary least squares (OLS). Sementara itu, bila residual dari model yang terpilih melanggar asumsi homoskedastisitas dan/atau non-autokorelasi maka metode estimasi yang dapat digunakan adalah generalized least squares (GLS) atau feasible generalized least squares (FGLS).

3. Pengujian keberartian model dilakukan pada model yang telah terpilih sebagai model terbaik. Pengujian ini terdiri dari uji simultan (uji F), uji parsial (uji t), dan kemampuan model dengan melihat nilai adjusted $\mathrm{R}^{2}$.

\section{HASIL DAN PEMBAHASAN}

\section{Perkembangan Produktivitas Pekerja di Sektor Perdagangan, Rumah Makan, dan Jasa Akomodasi}

Pembangunan merupakan salah satu fokus penting bagi negara yang sedang berkembang, seperti Indonesia. Ukuran yang tepat digunakan untuk menggambarkan pembangunan suatu negara atau daerah adalah produktivitas pekerja. Produktivitas pekerja yang tinggi dapat meningkatkan standar hidup seseorang. Bila produktivitas pekerja di suatu wilayah mengalami peningkatan maka standar hidup masyarakat yang merupakan bagian dalam wilayah tersebut juga akan meningkat sehingga kesejahteraan tercapai.

Salah satu sektor yang dominan dalam menyerap pekerja di Indonesia adalah sektor perdagangan, rumah makan, dan jasa akomodasi. Sebanyak $23,28 \%$ penduduk usia lima belas tahun ke atas yang bekerja diserap oleh sektor perdagangan, rumah makan, dan jasa akomodasi pada tahun 2017 (BPS, 2017b). Oleh karena itu, perkembangan produktivitas pekerja di sektor ini perlu diperhatikan untuk mencerminkan pembangunan di Indonesia.

Perkembangan produktivitas pekerja ini dapat dilihat pada provinsi-provinsi yang juga dominan di sektor perdagangan, rumah makan, dan jasa akomodasi. Beberapa provinsi di Indonesia yang dominan di sektor perdagangan, rumah makan, dan jasa akomodasi, yaitu provinsi yang memiliki share PDRB sektor tersebut tertinggi pertama dan kedua, adalah provinsi Aceh, Sumatera Barat, 
Bengkulu, DKI Jakarta, Jawa Barat, Jawa Tengah, DI Yogyakarta, Jawa Timur, Banten, Bali, Sulawesi Utara, Sulawesi Selatan, Gorontalo, dan Sulawesi Barat.

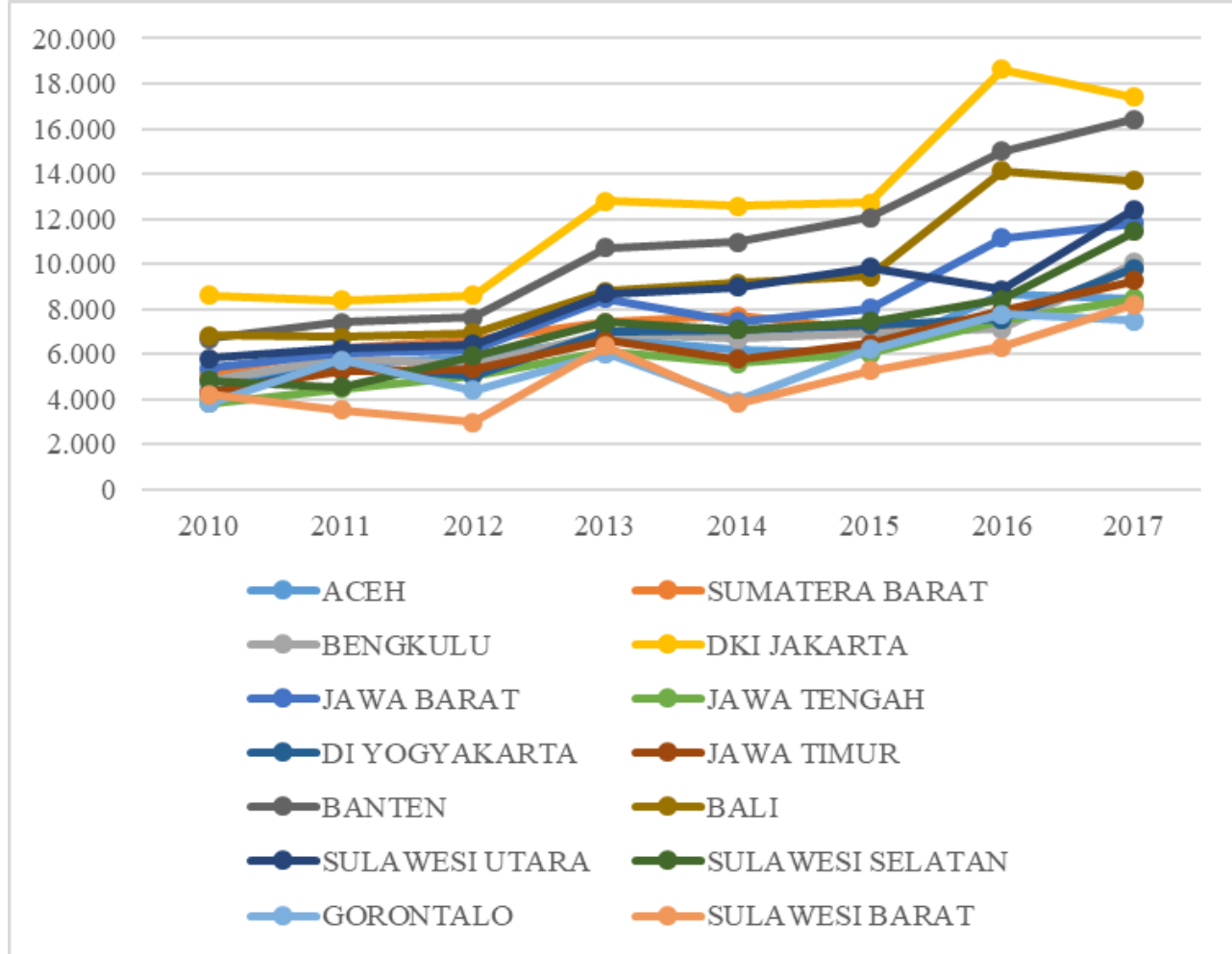

Gambar 2. Perkembangan produktivitas pekerja (rupiah per jam) menurut 14 provinsi dominan sektor perdagangan, rumah makan, dan jasa akomodasi tahun 2010-2017.

Berdasarkan Gambar 2 di atas, produktivitas pekerja sektor perdagangan, rumah makan, dan jasa akomodasi di 14 provinsi yang dominan sektor tersebut meskipun berfluktuasi, polanya cenderung meningkat dari tahun 2010 sampai tahun 2017. Hal ini menunjukkan bahwa kemampuan pekerja untuk memperoleh upah semakin meningkat sehingga standar hidupnya meningkat. Provinsi yang memiliki nilai produktivitas pekerja tertinggi adalah DKI Jakarta. Produktivitas yang tinggi dikarenakan Provinsi DKI Jakarta memiliki rata-rata upah tertinggi bila dibandingkan dengan provinsi lain. Sementara itu, produktivitas pekerja terendah terjadi di Provinsi Sulawesi Barat, yang disebabkan oleh rata-rata upah yang rendah dan fluktuatif dari tahun 2010-2015.

Bila ditinjau lebih detail, pada tahun 2013, semua provinsi mengalami peningkatan produktivitas pekerja. Hanya saja, pada tahun 2014, secara rata-rata, produktivitas pekerjanya menurun. Hal ini disebabkan oleh rata-rata jam kerja yang meningkat di semua provinsi dominan, kecuali Sulawesi Utara yang mengalami stagnasi jam kerja. Sementara itu, di beberapa provinsi, seperti Aceh, Bengkulu, Jawa Barat, Jawa Timur, Gorontalo, dan Sulawesi Barat, peningkatan jam kerja ini diiringi dengan penurunan rata-rata upah. Hal ini yang menyebabkan produktivitas pekerja pada tahun 2014 cenderung menurun.

Selain itu, dapat dilihat pada Gambar 2 bahwa pada tahun 2010 sampai 2012, perbedaan antara produktivitas pekerja tertinggi dan terendah cenderung lebih kecil. Produktivitas pekerja di 14 provinsi pada periode tersebut lebih seragam. Namun, perbedaan produktivitas pekerja ini semakin melebar sampai tahun 2016. Perbedaan pada tahun ini merupakan yang tertinggi dibandingkan tahun lainnya. Diketahui bahwa produktivitas pekerja pada tahun 2016 di DKI Jakarta bernilai hampir tiga kali lipat dari produktivitas pekerja di Sulawesi Barat. Perbedaan produktivitas pekerja antara kedua provinsi ini adalah sebesar Rp 12.326,83 per jam.

\section{Faktor Karakteristik Pekerja yang Memengaruhi Produktivitas di Sektor Perdagangan, Rumah Makan, dan Jasa Akomodasi}


Untuk menganalisis faktor karakteristik pekerja yang memengaruhi produktivitas di sektor perdagangan, rumah makan, dan jasa akomodasi dengan analisis regresi data panel, dilakukan tahapan-tahapan sebagai berikut:

1. Pemilihan model produktivitas pekerja

Hasil pengolahan uji hausman menghasilkan statistik chi-square sebesar 6,1163 dengan $p$-value 0,2951 (Lampiran 1). Dengan tingkat signifikansi 5\%, pengujian diputuskan gagal tolak $\mathrm{H}_{0}$ dan dapat disimpulkan bahwa random effects mode/lebih baik daripada fixed effects model. Dengan demikian, dapat disimpulkan bahwa model produktivitas pekerja sektor perdagangan, rumah makan, dan jasa akomodasi adalah menggunakan random effects model(REM).

2. Pengujian asumsi regresi untuk random effects model

Random effects model tidak dapat memenuhi asumsi non-autokorelasi sehingga metode estimasi yang sesuai untuk model ini adalah metode GLS (Gujarati \& Porter, 2009). Pada pengujian asumsi normalitas, dihasilkan statistik Jarque Berra sebesar 2,4514 dengan p-value 0,2936 (Lampiran 2). Pada tingkat signifikansi $5 \%$, pengujian diputuskan gagal tolak $\mathrm{H}_{0}$ dan dapat disimpulkan bahwa residual REM bersifat normal. Selanjutnya, dilakukan pemeriksaan asumsi nonmultikolinieritas dengan melihat nilai Variance Inflation Factor (VIF) dari masing-masing variabel bebas. Hasil pemeriksaan (Lampiran 3) menunjukkan bahwa semua variabel bebas memiliki nilai VIF kurang dari 10, yang berarti bahwa tidak terjadi multikolinieritas antar variabel bebas dalam model. Dengan demikian, asumsi regresi REM pada penelitian ini sudah terpenuhi.

3. Pengujian keberartian model produktivitas pekerja

Pada model yang terpilih, dihasilkan output sebagai berikut:

Tabel 1. Hasil uji random effects model.

\begin{tabular}{|c|c|c|c|c|c|}
\hline Variabel & Koefisien & Std. Eror & Statistik t & Prob. & \\
\hline$(1)$ & (2) & (3) & $(4)$ & $(5)$ & \\
\hline C & 7,151264 & 0,263106 & 27,18015 & 0,0000 & \\
\hline JK & 0,003367 & 0,003396 & 0,991558 & 0,3237 & \\
\hline PENDIDIKAN & 0,009535 & 0,002870 & 3,322240 & 0,0012 & $* *$ \\
\hline PENGALAMAN & 0,006739 & 0,003572 & 1,886256 & 0,0620 & $*$ \\
\hline UMP & $4,33 \mathrm{E}-07$ & $3,23 \mathrm{E}-08$ & 13,41122 & 0,0000 & $* *$ \\
\hline PEKERJA & $3,36 \mathrm{E}-07$ & $8,17 \mathrm{E}-08$ & 4,107949 & 0,0001 & $* *$ \\
\hline \multicolumn{6}{|c|}{ Hasil uji } \\
\hline Statistik F & & 72,51894 & & & \\
\hline Prob(Statistik F) & & 0,000000 & & & \\
\hline
\end{tabular}

Keterangan: ${ }^{* *}$ Signifikan pada tingkat signifikansi $5 \%$; *tingkat signifikansi $10 \%$

Berdasarkan Tabel 1, dapat dilihat nilai statistik $\mathrm{F}$ sebesar 72,5189 dengan $p$-value 0,0000. Dengan tingkat signifikansi $5 \%$, keputusan dari uji $\mathrm{F}$ adalah tolak $\mathrm{H}_{0}$ yang berarti bahwa dari model yang dihasilkan, terdapat minimal satu variabel bebas yang signifikan memengaruhi produktivitas pekerja di sektor perdagangan, rumah makan, dan jasa akomodasi.

Selanjutnya, hasil statistik $t$ dari masing-masing variabel bebas pada Tabel 1 menunjukkan bahwa tingkat pendidikan pekerja (PENDIDIKAN), tingkat upah (UMP), dan jumlah pekerja (PEKERJA) berpengaruh terhadap produktivitas pekerja pada tingkat signifikansi $5 \%$, sedangkan pengalaman kerja (PENGALAMAN) berpengaruh terhadap produktivitas pekerja pada tingkat signifikansi $10 \%$.

Sementara itu, variabel jenis kelamin (JK) memberikan hasil yang tidak signifikan dalam memengaruhi produktivitas pekerja karena statistik $t$ yang dihasilkan adalah sebesar 0,9916 dengan $p$-value 0,3237 sehingga keputusan uji $\mathrm{t}$ adalah gagal tolak $\mathrm{H}_{0}$. Hasil ini bertentangan dengan penelitian sebelumnya, seperti dalam penelitian Herawati (2013) yang menghasilkan variabel jenis kelamin berpengaruh positif terhadap produktivitas pekerja. Hasil yang tidak signifikan pada penelitian ini dimungkinkan karena produktivitas pekerja sektor perdagangan, rumah makan, dan jasa akomodasi di Indonesia ini cenderung tidak berbeda jauh antara laki-laki dan perempuan, dengan selisih sebesar Rp 2.278 per jam pada tahun 2017. Selain itu juga peran perempuan di Indonesia mulai menunjukkan peningkatan modal manusia, yaitu ditandai dengan peningkatan 654 
persentase angka melek huruf dan rata-rata lama sekolah untuk jenis kelamin perempuan (BPS, 2018a \& 2018c). Terdapat pula teori pendukung yang menyatakan bahwa dalam riset yang dilakukan oleh Ragins, Townsend, dan Mathis (1998) telah membuktikan bahwa laki-laki dan perempuan memiliki persamaan dalam kemampuan belajar, memori, kemampuan penalaran, kreativitas, dan intelijen. Hal ini dapat dikatakan bahwa jenis kelamin tidak memengaruhi kemampuan seseorang, termasuk produktivitasnya.

Untuk prediksi nilai produktivitas pekerja di 14 provinsi, berikut ini ringkasan estimasi untuk model dengan faktor karakteristik pekerja yang signifikan, yaitu tingkat pendidikan pekerja, pengalaman kerja, tingkat upah, dan jumlah pekerja.

Tabel 2. Hasil estimasi random effects dengan GLS pada model prediksi.

\begin{tabular}{llccc}
\hline \multicolumn{1}{c}{ Variabel } & Koefisien & \multicolumn{1}{c}{ Std. Eror } & Statistik t & \multicolumn{1}{c}{ Prob. } \\
\hline \multicolumn{1}{c}{$(1)$} & $(2)$ & $(3)$ & $(4)$ & $(5)$ \\
\hline C & 7,340429 & 0,177543 & 41,34450 & 0,0000 \\
PENDIDIKAN & 0,009883 & 0,002836 & 3,484152 & 0,0007 \\
PENGALAMAN & 0,006928 & 0,003561 & 1,945885 & 0,0543 \\
UMP & $4,26 \mathrm{E}-07$ & $3,16 \mathrm{E}-08$ & 13,50588 & 0,0000 \\
PEKERJA & $3,34 \mathrm{E}-07$ & $8,03 \mathrm{E}-08$ & 4,160849 & 0,0001 \\
\hline \multicolumn{5}{c}{ Hasil uji } \\
\hline R-squared & & 0,771274 & \\
Adjusted $\boldsymbol{R}$-squared & & 0,762723 & \\
Statistik F & & 90,20209 & \\
Prob(Statistik F) & & 0,000000 & \\
\hline
\end{tabular}

Berdasarkan hasil pengolahan pada Tabel 2, dapat diketahui bahwa tingkat upah, jumlah pekerja, dan tingkat pendidikan pekerja berpengaruh positif terhadap produktivitas pekerja pada tingkat signifikansi 5\%, sedangkan pengalaman kerja berpengaruh positif terhadap produktivitas pekerja pada tingkat signifikansi $10 \%$. Sementara itu, nilai adjusted $R$-squared adalah sebesar 0,7627 yang berarti bahwa kemampuan tingkat upah, jumlah pekerja, tingkat pendidikan pekerja, dan pengalaman kerja dalam menjelaskan keragaman produktivitas pekerja sektor perdagangan, rumah makan, dan jasa akomodasi di 14 provinsi yang dominan sektor tersebut adalah sebesar $76,27 \%$, sedangkan sisanya dijelaskan oleh variabel bebas lainnya yang tidak tercakup dalam model.

Hasil estimasi model produktivitas pekerja sektor perdagangan, rumah makan, dan jasa akomodasi di 14 provinsi yang tertera pada Tabel 2 dapat disusun menjadi persamaan berikut:

$$
\begin{aligned}
& L N_{-} \widehat{P R O} D_{l t}=7,34+0,0099 P E N D I D I K A N_{i t}+0,0069 P E N G A L A M A N_{i t}+4,26 \times 10^{-7} \text { UMP }_{i t}+ \\
& 3,34 \times 10^{-7} \text { PEKERJA }
\end{aligned}
$$

dengan cross-section random effects yang dihasilkan dari model di atas adalah sebagai berikut: 
Tabel 3. Cross-section random effects.

\begin{tabular}{|c|c|c|c|}
\hline Provinsi & Effect & GORONTALO & 0,01133 \\
\hline (1) & (2) & SULAWESI BARAT & $-0,01889$ \\
\hline BANTEN & 0,31336 & JAWA BARAT & $-0,04137$ \\
\hline BALI & 0,10503 & JAWA TENGAH & $-0,07982$ \\
\hline BENGKULU & 0,09882 & SULAWESI SELATAN & $-0,08347$ \\
\hline SUMATERA BARAT & 0,09157 & JAWA TIMUR & $-0,14257$ \\
\hline DI YOGYAKARTA & 0,03439 & DKI JAKARTA & $-0,15634$ \\
\hline SULAWESI UTARA & 0,02881 & $\mathrm{ACEH}$ & $-0,16085$ \\
\hline
\end{tabular}

Hasil cross-section random effects pada Tabel $\mathbf{3}$ di atas menunjukkan bahwa saat semua variabel bebas konstan, provinsi yang memiliki produktivitas pekerja tertinggi adalah Banten, yaitu sebesar 0,3134 atau sebesar Rp 1,3681 per jam. Hal ini sesuai dengan hasil deskriptif pada Gambar 2, yaitu Provinsi Banten yang memiliki produktivitas pekerja yang tinggi. Sementara itu, provinsi yang memiliki produktivitas pekerja terendah adalah Aceh. Hasil ini juga sesuai dengan deskriptif pada Gambar 2 yang menunjukkan Provinsi Aceh termasuk dalam provinsi yang memiliki produktivitas pekerja pada urutan 5 terendah. Efek inilah yang membedakan karakteristik dari masing-masing provinsi yang tidak dapat dicakup dalam model, yaitu yang tertuang dalam komponen yang tidak mencakup variabel bebas dalam penelitian (eror). Provinsi-provinsi yang memiliki cross-section random effects positif berarti bahwa penambahan variabel bebas ke dalam model akan meningkatkan produktivitas pekerja. Sementara itu, provinsi-provinsi yang memiliki cross-section random effects negatif berarti bahwa penambahan variabel bebas yang tidak tercakup dalam model ini justru dapat menurunkan produktivitas pekerja.

Berdasarkan persamaan (2), tingkat upah memberikan pengaruh positif terhadap produktivitas pekerja. Koefisien yang dihasilkan adalah sebesar 0,000000426. Hasil ini memberikan makna bahwa jika upah minimum provinsi (UMP) meningkat 1 rupiah maka produktivitas pekerja akan meningkat sebesar 0,0000426\% dengan syarat variabel bebas lainnya konstan. Atau dapat dikatakan bila UMP meningkat sebesar Rp 10.000 maka produktivitas pekerja akan meningkat sebesar 0,426\%, dengan variabel lain konstan. Pengaruh positif yang diberikan oleh variabel tingkat upah terhadap produktivitas pekerja ini relevan dengan penelitian Herawati (2013) dan Adhadika (2014). Selain itu, hasil ini juga sesuai dengan teori efisiensi upah, yaitu semakin tinggi upah maka pekerja semakin mampu memenuhi kebutuhan gizi hidupnya sehingga membuat pekerja lebih produktif (Mankiw, 2009).

Hasil pada Tabel $\mathbf{2}$ menunjukkan bahwa jumlah pekerja berpengaruh terhadap produktivitas pekerja secara signifikan. Koefisien dari variabel jumlah pekerja pada persamaan (2) adalah sebesar 0,000000334 yang berarti bahwa jika jumlah pekerja bertambah 1 jiwa maka produktivitas pekerja akan meningkat sebesar 0,0000334\% dengan variabel lainnya konstan. Atau dapat dikatakan jika jumlah pekerja meningkat sebanyak 10.000 jiwa maka produktivitas pekerja akan meningkat sebesar 0,334\%, dengan variabel lain konstan. Hal ini berarti bahwa semakin bertambahnya jumlah pekerja maka produktivitas pekerja akan semakin meningkat. Hasil ini sesuai dengan hipotesis penelitian yang telah dibuat sebelumnya dan relevan dengan teori yang terkait. Fungsi produksi Cobb-Douglas menunjukkan bahwa jumlah pekerja berbanding lurus dengan jumlah output yang dihasilkan (Borjas, 2013). Hal ini berarti bahwa semakin banyaknya jumlah pekerja maka produksi yang dihasilkan akan semakin banyak juga. Produksi yang tinggi inilah yang mencerminkan adanya produktivitas yang tinggi.

Selanjutnya, tingkat pendidikan pekerja berpengaruh positif terhadap produktivitas pekerja. Koefisien bernilai sebesar 0,0099 berarti bahwa jika persentase pekerja dengan ijazah SMA/sederajat ke atas meningkat 1 persen dan variabel lainnya konstan, maka produktivitas pekerja akan meningkat sebesar 0,99\%. Hasil penelitian ini sesuai dengan hipotesis yang telah dibuat dan penelitian terkait sebelumnya. Penelitian Forbes, Barker \& Turner (2010) dan Adhadika (2014) juga menghasilkan pendidikan berpengaruh positif terhadap produktivitas pekerja. Selain itu, hasil penelitian ini juga relevan dengan teori terkait dalam ekonomi ketenagakerjaan. Sebagaimana yang dinyatakan oleh Borjas (2013), bahwa pekerja yang berinvestasi dalam pendidikan akan 656 
memperoleh pendapatan yang lebih tinggi di masa depan. Dengan demikian, semakin meningkatnya persentase pekerja dengan ijazah SMA/sederajat ke atas, maka produktivitas pekerja akan semakin meningkat juga, dengan syarat variabel lainnya konstan.

Pengalaman kerja berpengaruh positif terhadap produktivitas pekerja di sektor perdagangan, rumah makan, dan jasa akomodasi pada tingkat signifikansi $10 \%$. Koefisien yang dihasilkan oleh variabel pengalaman kerja adalah sebesar 0,0069, yang berarti bahwa saat lama bekerja dari pekerja meningkat 1 bulan, sementara variabel bebas lainnya konstan, maka produktivitas pekerja akan meningkat sebesar 0,69\%. Hasil ini menunjukkan bahwa pengalaman kerja ini juga memberikan pengaruh positif. Hasil penelitian ini juga sesuai dengan penelitian Herawati (2013) dan Adhadika (2014) yang menunjukkan adanya pengaruh positif pengalaman terhadap produktivitas pekerja. Pengaruh positif ini dikarenakan semakin lama seorang pekerja bekerja dalam suatu pekerjaan, maka semakin meningkat keahlian dan keterampilan pekerja tersebut sehingga produktivitasnya semakin meningkat.

\section{KESIMPULAN}

Berdasarkan hasil analisis dan pembahasan yang telah dijabarkan sebelumnya, dihasilkan kesimpulan bahwa perkembangan produktivitas pekerja sektor perdagangan, rumah makan, dan jasa akomodasi di 14 provinsi pada tahun 2010 sampai 2017 mengalami fluktuasi namun cenderung meningkat dan didapatkan bahwa variabel tingkat upah, jumlah pekerja, tingkat pendidikan pekerja, dan pengalaman kerja berpengaruh positif dan signifikan terhadap produktivitas pekerja. Dengan demikian, disarankan agar lebih meningkatkan produktivitas pekerja melalui peningkatan upah minimum provinsi agar menjadi daya tarik pekerja karena sektor perdagangan, rumah makan, dan jasa akomodasi ini merupakan penyumbang PDB Indonesia tertinggi kedua. Selain itu, peningkatkan pendidikan penduduk yang akan masuk ke dalam pasar tenaga kerja, khususnya di sektor perdagangan, rumah makan, dan jasa akomodasi juga diperlukan dan unit usaha di sektor tersebut hendaknya mengurangi pekerja kontrak dan mempekerjakan pekerja dengan kontinuitas yang panjang agar lebih terampil. Provinsi-provinsi yang memiliki cross-section random effects positif perlu menambahkan variabel bebas lain yang tidak tercakup dalam model untuk dapat meningkatkan produktivitas pekerja. Sementara itu, provinsi-provinsi yang memiliki cross-section random effects negatif perlu mempertahankan atau meningkatkan variabel-variabel yang tercakup dalam model ini, seperti tingkat upah, jumlah pekerja, tingkat pendidikan pekerja, dan pengalaman kerja.

\section{DAFTAR PUSTAKA}

Adhadika, T. (2014). Analisis Faktor-faktor yang Mempengaruhi Produktivitas Tenaga Kerja Industri Pengolahan di Kota Semarang (Studi Kecamatan Tembalang dan Kecamatan Gunungpati). Diponegoro Journal of Economics, 1-13.

Borjas, G. J. (2013). Labor Economics Sixth Edition. New York: McGraw-Hill.

Badan Pusat Statistik. (2011). Keadaan Pekerja di Indonesia Agustus 2011. Jakarta: BPS. . (2014). Keadaan Pekerja di Indonesia Agustus 2014. Jakarta: BPS.

. (2015). Produk Domestik Regional Bruto Provinsi-provinsi di Indonesia menurut Lapangan Usaha 20102014. Jakarta: BPS.

(2017a). Keadaan Pekerja di Indonesia Agustus 2017. Jakarta: BPS.

- (2017b). Penduduk Bekerja menurut Status Pekerjaan Utama dan Lapangan Pekerjaan. Diunduh pada tanggal 18 Desember 2018 melalui https://www.bps.go.id/statictable/2016/04/05/1911/pendudukberumur-15-tahun-ke-atas-yang-bekerja-selama-seminggu-yang-lalu-menurut-status-pekerjaan-utamadan-lapangan-pekerjaan-2008---2017.html

. (2017c). Produk Domestik Bruto per Kapita Atas Dasar Harga Konstan 2010. Diunduh pada tanggal 31 Oktober 2018 melalui https://www.bps.go.id/statictable/2015/09/29/1866/perkembangan-produkdomestik-bruto-dan-produk-domestik-bruto-per-kapita-atas-dasar-harga-konstan-2010-2010-2016.html

. (2018a). Persentase Angka Melek Huruf (AMH) Penduduk Usia 15 Tahun Ke Atas menurut Jenis Kelamin. Diunduh pada tanggal 24 Juni 2019 melalui https://www.bps.go.id/dynamictable/2018/07/13/1539/persentase-angka-melek-huruf-amh-pendudukusia-di-atas-15-tahun-menurut-jenis-kelamin-2011-2018.html 
. (2018b). Produk Domestik Regional Bruto Provinsi-provinsi di Indonesia menurut Lapangan Usaha 2013-2017. Jakarta: BPS.

. (2018c). Rata-rata Lama Sekolah Penduduk Usia 15 Tahun Ke Atas menurut Jenis Kelamin. Diunduh pada tanggal 24 Juni 2019 melalui https://www.bps.go.id/dynamictable/2018/06/29/1510/rata-ratalama-sekolah-penduduk-umur-15-tahun-menurut-jenis-kelamin-2011---2018.html

Forbes, M., Barker, A., \& Turner, S. (2010). The Effects of Education and Health on Wages and Productivity. Melbourne: Productivity Commission.

Gujarati, D. N., \& Porter, D. C. (2009). Basic Econometrics Fifth Edition. New York: McGraw-Hill.

Herawati, N. (2013). Analisis Pengaruh Pendidikan, Upah, Pengalaman Kerja, Jenis Kelamin, dan Umur terhadap Produktivitas Tenaga Kerja Industri Shuttlecock Kota Tegal. Diponegoro Journal of Economics, $1-8$.

ILO. (2015). KILM 16. Labour Productivity.

Mankiw, N. G. (2009). Macroeconomics Seventh Edition. New York: Worth Publishers.

OECD. (2018). OECD Compendium of Productivity Indicators 2018. Paris: OECD Publishing.

Ragins, B. R., Townsend, B., \& Mathins, M. (1998). Gender Gap in the Executive Suite: CEOs and Female Executives Report on Breaking the Glass Ceiling. Academy of Management Executive, 28-42.

Todaro, M. P., \& Smith, S. C. (2015). Economic Development Twelfth Edition. New Jersey: Pearson Education.

\section{LAMPIRAN}

Lampiran 1. Uji Hausman

Correlated Random Effects - Hausman Test

Test cross-section random effects

\begin{tabular}{lrrr}
\hline \hline Test Summary & $\begin{array}{r}\text { Chi-Sq. } \\
\text { Statistic }\end{array}$ & Chi-Sq. d.f. & Prob. \\
\hline \hline Cross-section random & 6.116295 & 5 & 0.2951 \\
\hline \hline
\end{tabular}

Lampiran 2. Asumsi Normalitas

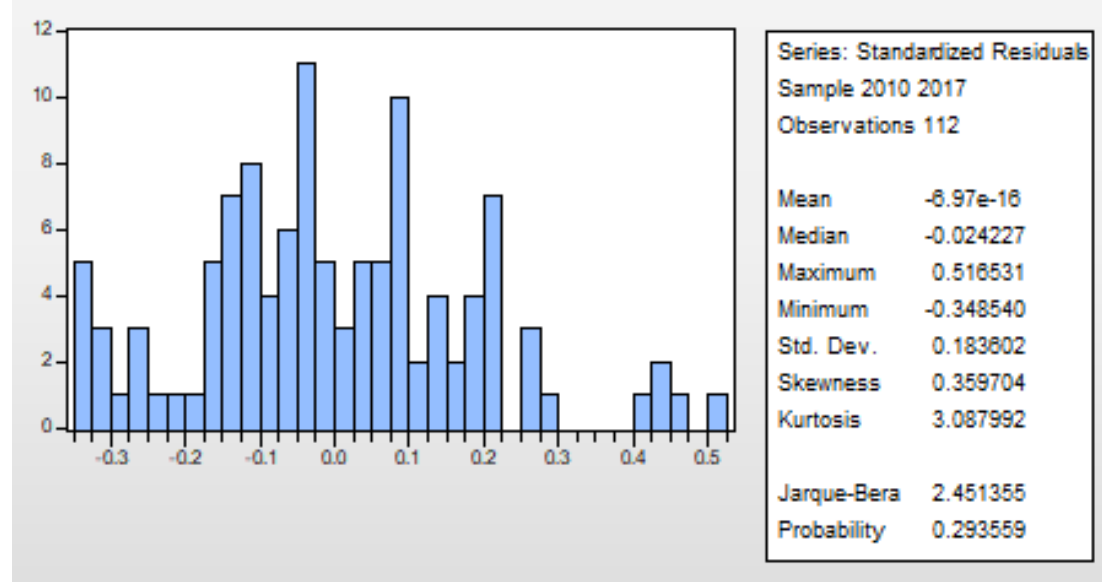


Faktor Karakteristik Pekerja terhadap Produktivitas di Sektor Perdagangan, Rumah Makan, dan Jasa Akomodasi Tahun 20102017.

Lampiran 3. Pemeriksaan Asumsi Non-multikolinieritas

Variance Inflation Factors

Sample: 20102017

Included observations: 112

\begin{tabular}{cccc}
\hline \hline Variable & $\begin{array}{c}\text { Coefficient } \\
\text { Variance }\end{array}$ & $\begin{array}{c}\text { Uncentered } \\
\text { VIF }\end{array}$ & $\begin{array}{c}\text { Centered } \\
\text { VIF }\end{array}$ \\
\hline \hline C & 0.069225 & 43.05731 & NA \\
JK & $1.15 \mathrm{E}-05$ & 28.02279 & 1.045163 \\
PENDIDIKAN & $8.24 \mathrm{E}-06$ & 21.83853 & 1.285302 \\
PENGALAMAN & $1.28 \mathrm{E}-05$ & 7.416265 & 1.196666 \\
UMP & $1.04 \mathrm{E}-15$ & 2.530255 & 1.307634 \\
PEKERJA & $6.68 \mathrm{E}-15$ & 1.756927 & 1.150687 \\
\hline \hline
\end{tabular}

